\title{
East Birmingham: running faster on the spot
}

\author{
Tony Delamothe
}

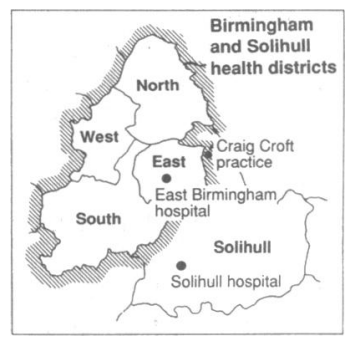

Nothing much has changed in East Birmingham Health Authority since the NHS reforms were introduced on 1 April: take off has been smooth. No one has examples of the changes benefiting or harming patient care. Although "progress" in the past six months may be nil, activity has become ever more frenetic. Conversations with doctors and managers left me with the impression that everyone was running very much faster in East Birmingham, but on the spot.

Given the apocalyptic predictions, the lack of surprises was the most surprising feature of the past few months for some I spoke to. But why should there have been surprises? This year purchasers had no option but to place contracts according to past referral patterns; the district has no self governing trusts or fundholding general practices - two of the "wild cards" of the new reforms.

That other wild card, the extracontractual referral, wasn't causing any problems. General practitioners were "very pleased" with how the district purchasers had been managing them. So far the director of corporate management, Mrs Wai-Yin Hatton, had agreed every request and was still within budget $(2 \%$ of the budget was for extracontractual referrals). Whenever the district agreed an expensive referral it reminded the general practitioner of the impact the referral would have on local providers. Appointing a local general practitioner to the purchasing board had been shrewd - "creating useful dialogue with GPs was easier using someone from the same profession," said Mrs Hatton.

East Birmingham has no fundholding general practices, and no practices have expressed interest in becoming fundholders next year. If the district purchasers continue to be so responsive to their needs perhaps they never will. In any case the larger practices are said to be philosophically opposed to the idea; the smaller ones lack the patient numbers and infrastructure (half are single handed). They don't support the application of their local district general hospital, East Birmingham, for self governing status, voting six to one against the idea.

They view the reforms as potentially too destabilising. Looking eastwards to Solihull district they see that fundholders "have not been slow to move the services around." Next year one third of Solihull's residents will be patients of fundholding practices. If the practices radically alter their referral patterns and district purchasers exercise their new freedom to place contracts where they like (rather than according to past referral patterns) chaos might follow.

\section{The fundholder next door}

Some of Solihull's fundholders refer their patients to East Birmingham Hospital. When I spoke to Dr Ken Dawson of the Craig Croft practice earlier this year he was hoping for some more flexibility from East Birmingham Hospital over its contracts. At the time the hospital had decided against expending a disproportionate amount of energy to secure fundholders' business, reckoning that it would amount to less than $0.4 \%$ of their budget. Soon afterwards, according to Dr Dawson, East Birmingham capitu-

lated and offered them any contract they likedpreviously they had been offered only block contracts.

East Birmingham Hospital has lost Craig Croft's ophthalmological referrals to Coventry and pathology requests to Solihull, but Dr Dawson thinks that his practice's overall referral pattern has not changed much. The practice has possibly referred slightly more surgical cases to Birmingham General Hospital, where prices are cheaper, waiting lists shorter, and the quality of services just as good. Birmingham General is threatened with closure, and some have attributed its cut throat pricing to a last ditch attempt to attract business. "It's a bit of an institution, which everyone wants to keep open: you could say we're doing our bit," said Dr Dawson.

Despite Craig Croft's activity levels staying about the same this year current projections suggest an underspend of $£ 120000$ on its annual budget of $£ 700000$ for hospital services. This is probably an exaggeration, thinks Dr Dawson, because many early bills have not come through. After four months their drug budget is "spot on." (Initially, they tried hard to change their prescribing habits-"all getting into generics" - and saved $£ 8000$ in the first month. In July, however, they overspent by $£ 5000$.)

Fundholding has required additional staff. A medical secretary has become a budget manager, and a new secretary and a second practice manager (the first is on maternity leave) have been appointed. The new salaries are covered by the practice's $£ 33000$ management allowance.

What is new is their contracting of a local surgeon to provide a weekly clinic in the practice, where 12-15 patients are seen each time. This "regularises what was previously an ad hoc arrangement" and saves the practice money. A local outpatient appointment would cost about $£ 50-£ 60$; this way the practice gets it for about $£ 20$ and the costs of investigations are cheaper. The waiting time is never more than a fortnight compared with several months for the outpatient clinic.

\section{Providers: bringing it all back home?}

At East Birmingham Hospital Mr Robert Naylor, unit general manager, is feeling more confident now that "we've got from April to September without any major problems and the market hasn't crashed." Billing district health authorities has not been a problem because their computers are compatible. Fundholders' computers are incompatible, however: they still have to be sent hard copy. For the first three months they were $£ 85000$ underspent (last year they overspent by nearly $£ 0.5 \mathrm{~m}$ ). The revenue expected from fundholders is holding up; and extracontractual referrals are probably up on budget because purchasers were lenient early on. Now they seem to be cracking down.

Underlying this crackdown, $\mathrm{Mr}$ Naylor believes, is purchasers' loyalty to their own district providers. Did he think his local purchasers would remain loyal to East Birmingham Hospital, especially if it became a self governing trust?

$\mathrm{Mr}$ Naylor believes that a close affinity exists with his purchasers - "after all, we're on the same site, and 
we see each other in the dining room," he said. "They are helping us improve our areas of weakness-for example, they will redirect patient flows to allow us to appoint a third urologist, an extremely positive use of the new arrangements." He wondered whether other purchasers would retaliate.

He thought that purchasers were concerned with quality, access, and price-and his hospital was working hard on all three. It was meeting quality standards to a "fairly high degree." East Birmingham Hospital's long term waiting list (longer than two years) was the shortest in the West Midlands region. Prices, he thought, were about average. (Initially they had been substantially higher than, for example, at Birmingham General, which has since revised its prices upwards, according to Mr Naylor.) East Birmingham's hospital information support system (HISS) will be able to produce more accurate costs than this year's "guestimates," although not until well into next year. Meanwhile clinical directors are busy working with newly appointed specialist managers. Vast amounts of new information are needed, and increasingly consultants are being asked to participate in the development of computerised projects, particularly for clinical audit.

At present East Birmingham Hospital is not actively promoting its services to attract (or retain) business "everyone has been so heavily involved in consultation." Mr Naylor believes that the hospital must get much closer to general practitioners. "In future they will be more influential: they will be deciding patient referrals." Before 1 April Birmingham General Hospital had invited local general practitioners for tea and buns and asked them how they could help: as a result more day surgery has been provided.

\section{A trust next year?}

If its application for self governing status is successful East Birmingham Hospital will next year be a trust. During the consultation period Mr Naylor made over 30 presentations, mainly to hospital staff, although there were three public meetings. The hospital consultants voted 2:1 against applying for trust status, but the unit management board, on which sit five senior consultants, decided to submit the application anyway. Last month the medical staff committee debated that decision and resolved to note that the application had gone forward.

Dr Rowland Hopkinson, clinical director of anaesthetics and intensive care, is one of the five consultants on the unit management board. "I'm not espousing the government's cause, but East Birmingham's," he said. Dr Hopkinson disapproves of the wholesale implementation of the changes. Some of the proposals in Working for Patients he found interesting, but he believed they needed piloting. But given East Birmingham Hospital's special circumstances-its need to develop services and the building of new hospitals nearby-Dr Hopkinson believed that trust status should be considered. "I realise I hold a fairly schizoid position," he said.

This position is, according to Mr Howard Shaw, district general manager, common. $\mathrm{Mr}$ Shaw has identified two schools of people: those who say "well the government has introduced a market; let's see if we can work with it," and those who are unsure of the market but who will try to use whatever mechanisms are around to advance the aims of their organisation.

\section{The public's voice}

Dr Hopkinson spoke of the "vast concern about the changes, the immense uncertainty" among hospital staff. It extends into the community, too. East Birmingham Community Health Council decided that it would take no public position on trust status until after it had consulted the public. It therefore sent leaflets to 80000 homes, canvassing local opinion about the trust application. Of the 1400 replies that were received, $97 \%$ were against. The exercise cost the Council $£ 4000$ (which left a large hole in its budget), $£ 1000$ of which was obtained from the local authority, which had received a petition requesting a public referendum on the decision. Another ballot - of people attending East Birmingham Hospital on one day - showed that $94 \%$ of people were against their hospital becoming a trust. Sir James Ackers, chairman of West Midlands Regional Health Authority, was recently presented with a 10000 signature petition protesting at East Birmingham Hospital's plans to opt out. "We are still hoping that the trust application will not be successful," said Mrs Head. "We understand that second wave applications need to have public backing."

Mrs Head has doubts about the financial viability of East Birmingham: last year it overspent by nearly $£ 0.5 \mathrm{~m}$. Referral patterns are set to change; Solihull, which this year will provide a quarter of East Birming ham Hospital's contract income, is getting its own district general hospital. Dr Hopkinson said that "the spectre of overspending" would persist for East Birmingham whether or not it remained as a directly managed unit. In March he had said that the issue of trusts versus directly managed units paled into insignificance beside the consequences of the split between purchasers and providers. Six months later he agreed that there had been opportunity costs attached to applying for trust status but that these were minor compared with those of contracting and computerising.

\section{The purchasers}

When I spoke to Mrs Hatton six months ago I couldn't decide whether she saw her role as essentially passive-placing contracts where general practitioners wanted to send their patients-or active-moving contracts around according to grander plan (in both cases regardless of the consequences for local providers). Redirecting patient flows to allow the appointment of a third urologist at East Birmingham looked active, although supportive of local providers as well. No big changes in contracts are planned for next year. "We don't have enough information yet to move business away from someone on the grounds of quality," she said. "We must be convinced that any change will benefit patients." At this stage quality specifications were still being built up. Providers were trying to improve; this was not the time for cracking big whips. "We're at the stage of discovering where providers have genuine difficulties and working with them towards improvement," said Mrs Hatton. "We're not being adversarial."

Were providers keeping up with the (fairly rudimentary) quality specifications attached to contracts? Reasonably well, it seemed. When they didn't - for example, by offering patients outpatient appointments too far in the future-general practitioners rang up to complain. The purchasers could then get back to the providers to put things right. This gave Mrs Hatton "great satisfaction": it meant that the system was working. But what if outpatient appointments were genuinely full; squeezing in an extra appointmen would mean extra work for hospital staff. Mrs Hatton didn't grasp my problem. The results of patient satisfaction surveys, to be conducted by providers, will not be available until later this year.

Mrs Hatton was upbeat about the future. "From management's point of view the opportunities are phenomenal; we're beginning to enjoy contracting now," she said. "We are starting to make improve- 
ments by moving money around. You can see the benefits coming - it's a helluva powerful weapon that, money."

Continuing the military analogies, Mr Howard Shaw, district general manager, likens the current situation to a phoney war. "Initially we were trying to turn money around and get into battle order, and we've just about done that, although by early September we still have one contract left to sign and education isn't sorted out."

By next spring Mr Shaw could envisage two scenarios: "frenetic activity that gets us somewhere new or frenetic activity that gets us nowhere." The only area in which he saw signs of improvement were in the provision of mental health services for East Birmingham. Previously, patients were cared for in hospitals in two neighbouring districts. Now that the district held the money for its patients it could more easily extricate itself from what it regarded as unsatisfactory arrangements. (This may lead to hospital closures, however, in the other districts.)

This looked like another example of purchasers' loyalty to their local providers. What did he think of East Birmingham Hospital's expectation that its local contracts were probably safe? Mr Shaw said that East Birmingham was a poor district, car ownership was low, and expecting people to travel miles for medical care was a "very middle class view."

\section{But what do the people of East Birmingham need?}

Dr Anne McConville, East Birmingham's "single handed" director of public health, described her local population and "their experience of life, death, and deprivation," in her first annual report, Better Health for East Birmingham. Her second report, Getting Started, takes the first tentative steps towards needs assessment. She has found enormous epidemiological gaps - she can use the Whitehall study for coronary artery disease, but only for men. Similar studies for different ethnic groups-particularly relevant to East Birmingham - don't exist. As elsewhere, use of services is being used as a proxy for need, but activity levels in local outpatient departments are probably extremely inaccurate measures of need.

Earlier in the year I detected enthusiasm for shifting resources from treatment to prevention and for telling providers "what services we want for our patients, rather than the other way around." How successful had she been? The logic of transferring money spent on treating lung cancer to antismoking campaigns seemed flawless, but would patients, hospitals, and doctors accept it? "It's not a question of either/or," said Dr McConville, "we need both."

"We need more prevention, but we need more information to make rational choices about what we cut to fund it. Shifting resources is difficult when we don't have much information on the effectiveness of services. What I would find of use would be more consensus on common treatments of, for example, low back pain or glue ear."

Nothing Dr McConville has read has given her the information she needs to decide what proportion of her budget for coronary heart disease should go on angioplasties, bypass grafts, or thrombolytic drugs. So little consensus exists on so many treatments - "just think of the number of controversies in management you have highlighted in editorials in the $B M \mathcal{F}$ this year."

District health authorities haven't the resources or the information to decide these consensuses: this should happen at a national level, thought Dr McConville, with academic input. Until then, "You keep ticking over on the basis of what you're doing now unless you've got real evidence to change."

\section{Conclusion}

Like everyone I spoke to Dr McConville agreed that in the first six months of the NHS reforms there had been no chaos. "But have there been any benefits?" she asked. "They've consumed an awful lot of energy - at all levels." Benefits so far add up to a third urologist at East Birmingham Hospital and the possibility of more local mental health services.

"I can't see the changes improving patient care, given that we have the same amount of money to spend," said Dr Hopkinson. "Certainly we have more bureaucracy than before. There may have been some waste in the old system, but the costs of the new system more than make up for it."

I hope that somebody somewhere is keeping count: fundholders' $£ 33000$ management allowances and allowances for computers (which are incompatible with their providers' computers), the nearly $\$ 10 \mathrm{~m}$ that East Birmingham is spending on an information system to help it cost its services more accurately, and the salaries of specialist managers, invoicers, and computer staff.

Before we can assess the success or failure of the new reforms we will need to know how much more and better care they provided, at what cost, and whether they provided value for money.

\section{THE MEMOIR CLUB}

Both consultants and the general practitioners put their case for part time service in the NHS, and the right to have private practices even within the NHS buildings. Apart from the negotiation advantages of accepting these proposals, two things impressed Bevan. First, in America, the concept of "geographical full time" practice had grown up. This meant that specialists should work only under one roof, that of the hospital to which they were accredited, where there should be facilities for private practice within the hospital precincts. The difficulties of motoring in great cities, together with growing Harley Street rents, made geographical full time practice attractive to the specialists. Moreover, it provided better emergency care for both public and private patients. The other factor which influenced Bevan was his firm belief that the NHS must avoid the mistakes of the British educational system, with one service for the rich and another for the rest.

My concern was that the private sector within the NHS should not be so expensive as to take it completely beyond the means of the average citizen. I hoped that, like holidays in Spain, it would be a reasonable choice, available to those of all social classes who wanted to buy a little extra. Therefore, I argued that the price to the patient of private beds in the NHS should be subsidised, and the fees of the specialists also limited. Bevan accepted the latter (though it was later negotiated away) but not the former, because, in his view, the Labour party would not support it. He had had to reverse so many of their cherished shibboleths, and he felt he could do no more. As a result, private bed fees were fixed at their economic cost to the hospital, and soon they had escalated far beyond most people's means. They then became the perquisite of the rich (and the heavily insured), so that in the long term, the case for ending private practice inside the hospitals was strengthened greatly. The fine concept of "one service for all" has lost out.

From A Natural History of Everyday Life: A Biographical Guide for Would-be Doctors of Society by Lord Taylor of Harlow. Published under the BMF's Memoir Club imprint. ISBN 072790242 3. Price: Inland $£ 19.95$; abroad $£ 24.00$; USA $\$ 40.00$. BMA members: Inland $£ 18.95$; abroad $£ 23.00$; USA $\$ 38.00$. 